\title{
Profetyczny wymiar Centesimus annus. Analiza z perspektywy 30. rocznicy publikacji trzeciej encykliki społecznej Jana Pawła II
}

Opublikowana w 1987 roku druga encyklika społeczna Jana Pawła II Sollicitudo rei socialis w kluczowym, z punktu widzenia metodologicznego, punkcie 41 ostatecznie odrzuca dominujący, od encykliki Quadragesimo anno Piusa XI przez kilka dekad, model nauki społecznej Kościoła jako alternatywy dla dwóch dominujących nurtów życia społecznego - liberalizmu i socjalizmu. Równocześnie przypomina, że zadaniem Kościoła nie jest proponowanie gotowych systemów społeczno-ekonomicznych czy politycznych. Nie przedkłada on też gotowych recept i wzorców urządzenia poszczególnych obszarów społecznego wymiaru życia człowieka, lecz - jak to obrazowo wyrazili biskupi amerykańscy współżyjąc $\mathrm{w}$ dotychczasowej historii $\mathrm{z}$ wieloma formami organizacyjnymi życia gospodarczego i społecznego, chce pełnić dalej wobec nich funkcję krytyczną i zarazem profetyczną, oceniając każdy z tych systemów według zasad moralnych i etycznych, a poprzez integralną koncepcję człowieka i zasady społeczne ddziaływać na kształt życia społecznego w sposób konstruktywny i pozytywny².

Jan Paweł II postrzegał przez cały okres pontyfikatu magisterium społeczne jako jeden z uprzywilejowanych sposobów, dzięki któremu Kościół wyraża

${ }^{1}$ Jerzy Gocko - prof. dr hab., kierownik Katedry Teologii Moralnej Społecznej, Instytut Nauk Teologicznych KUL, e-mail: Jerzy@Gocko.pl, ORCID: 0000-0002-6513-5681.

${ }^{2}$ Por. List społeczny Episkopatu USA: Sprawiedliwość gospodarcza dla wszystkich. Katolicka nauka społeczna a gospodarka USA, (18 listopada 1986), w: Kościót wobec współczesnych problemów życia gospodarczego. Społeczne dokumenty episkopatów, red. S. Fel, J. Kupny, Lublin 2002, nr 130.

PST 40, 2021: 171-184. (C) The Author(s), Adam Mickiewicz University Press, 2021.

Open Access article, distributed under the terms of the CC licence (BY-NC-ND, https://creativecommons.org/licenses/by-nc-nd/4.0/). 
„społeczną troskę (sollicitudo rei socialis) o autentyczny rozwój człowieka i społeczeństwa", a zarazem wypełnia on swoje posłannictwo wobec świata na kanwie wydarzeń „zachodzących w ciągu dziejów”3. Nauczanie to charakteryzuje się z jednej strony ciągłością, ,gdyż pozostaje identyczne w swojej najgłębszej inspiracji, w «zasadach refleksji», w swoich «kryteriach ocen», a nade wszystko w wiernej i żywotnej więzi z Ewangelią Chrystusową"; z drugiej zaś jest ,zawsze nowe, gdyż podlega koniecznym i potrzebnym zmianom dyktowanym przez różne uwarunkowania historyczne i nieustanny bieg wydarzeń, pośród których upływa życie ludzi" (SRS 3). W nawiązaniu do powyższej interpretacji encyklika Centesimus annus doda, że nauka społeczna ujawnia „prawdziwe znaczenie Tradycji Kościoła”, jest skarbcem, który „niesie (...) «rzeczy stare», przejmowane i przekazywane od początku, i pozwala odczytywać «rzeczy nowe», wśród których żyje Kościół i świat”4.

We wprowadzeniu do encykliki Sollicitudo rei socialis papież określił nauczanie społeczne jako „refleksję teologiczną nad współczesną rzeczywistością" (SRS 4). Przyjmuje ona postać swoistej hermeneutyki, „w której spotykają się ze sobą w dynamice wiary i rozumu rzeczywistość, wobec której stoi człowiek i przyjmowane przez niego Boże Objawienie"5. Jej zadaniem jest z jednej strony zrozumienie świata $\mathrm{w}$ świetle Bożego objawienia, $\mathrm{z}$ drugiej zaś, stawianie temu objawieniu coraz to nowych pytań i odkrywanie nieznanych dotąd bogactw. Zadanie to przyjmuje formę ciągle uaktualnianego corpus doktrynalnego, który „rozwija się, w miarę jak Kościół, w pełności Słowa objawionego przez Jezusa Chrystusa i przy pomocy Ducha Świętego, odczytuje wydarzenia zachodzące w ciągu dziejów" (SRS 1). W ten sposób Kościół, odwołując się także do pomocy refleksji rozumowej oraz nauk o człowieku, wypełnia swoją misję pasterską wobec ludzi, prowadząc ich, aby „mogli realizować swoje powołanie odpowiedzialnych budowniczych ziemskiej społeczności” (SRS 1).

$\mathrm{Za}$ fundament (a zarazem i przejaw) profetyczno-krytycznego posłannictwa Kościoła w świecie należy uznać fakt, że proponuje ono i objawia światu prawdziwy i pełny obraz człowieka. „Kościół jest jedynym historycznym «miejscem», które gwarantuje prawdziwość teoretycznego poznania i praktycznej realizacji objawionej tożsamości człowieka”. Innymi słowy „,poza Kościołem (extra Ecclesiam) nie ma w ludzkim świecie innego «miejsca» umożliwiającego aktualiza-

3 Jan Paweł II, Encyklika Sollicitudo rei socialis, (30 grudnia 1987), Watykan: Libreria Editrice Vaticana 1988, nr 1 (dalej: SRS).

${ }^{4}$ Jan Paweł II, Encyklika Centesimus annus, (1 maja 1991), Watykan: Libreria Editrice Vaticana 1991, nr 3 (dalej: CA).

5 A. Zuberbier, Teologiczny wymiar encykliki ,, Rerum novarum”, ,Studia Theologica Varsaviensia" 30(1992), nr 1, s. 70. 
cję historycznej pełni tego poznawczego przeżywania"6. Pełna prawda o człowieku stanowi podstawę nie tylko społecznej doktryny Kościoła, ale także jego posłannictwa względem świata. Kwestia ta jest na tyle ważna, że soborowe przeświadczenie, że ośrodkiem życia społecznego we wszystkich jego obszarach jest człowiek - co oznacza przyznanie mu centralnego miejsca i roli w strukturach instytucji społecznych - nie wyczerpuje jeszcze omawianej problematyki. Kościół, świadomy możliwości różnych redukcji czy zafałszowań, „ukazuje równocześnie sens jego własnej egzystencji, to znaczy najgłębszą prawdę o człowieku"’.

Trzydziesta rocznica opublikowania przez Jana Pawła II encykliki Centesimus annus staje się doskonałą okazją, aby spojrzeć na nią pod kątem jej profetyczności, która - biorąc pod uwagę okoliczności wydania dokumentu była jej niejako organicznie przypisana. Przede wszystkim została ogłoszona w okrągłą, setną rocznicę encykliki o kwestii społecznej Rerum novarum Leona XIII, pierwszej encykliki społecznej, a zarazem umownego początku katolickiej nauki społecznej, co samo w sobie było już naturalną zachętą nie tylko do spojrzenia wstecz na mijające stulecie, ale także ku przyszłości. Po wtóre encyklika została ogłoszona krótko po klęsce ideologii komunistycznej oraz upadku systemu gospodarczego tworzonego w oparciu o zasadę kolektywizmu i centralnego sterowania, co postawiło kraje środkowej i Europy Środkowo-Wschodniej, w tym również i Polskę, wobec dylematu, w oparciu o jaki model społeczno-polityczny oprzeć swój dalszy rozwój. W sposób naturalny, choćby także przez zbieżność czasową, ale nie tylko, naprzeciw temu oczekiwaniu wychodziła trzecia encyklika społeczna Jana Pawła II Centesimus annus. Stała się ona konkretnym punktem odniesienia dla dokonujących się zmian nie tylko w naszej części Europy. Była głosem Kościoła, który, zgodnie z naturą nauki społecznej Kościoła i jej profetyczno-krytyczną specyfiką, ma prawo do wydawania osądu w sprawach społecznych, gdy domagają się tego podstawowe prawa osoby.

\section{Dokument na nowe czasy}

Wydarzenia roku 1989, upadek ideologii komunistycznej oraz systemu gospodarczego tworzonego w oparciu o zasadę kolektywizmu i centralnego sterowania, prędzej niż się spodziewano postawił kraje Europy Centralnej i Wschodniej, w tym również i Polskę, wobec dylematu, w oparciu o jaki model społeczno-

${ }^{6}$ J. Cuda, Praktyczno-społeczne kryterium wiarygodności objawionego sensu historii. Analityczno-syntetyczne studium inspirowane paradygmatem nowej teologii politycznej, Katowice 1999, s. 200-201.

${ }^{7}$ Sobór Watykański II, Konstytucja duszpasterska o Kościele w świecie współczesnym Gaudium et spes, (7 grudnia 1965), nr 41, w: Sobór Watykański II, Konstytucje. Dekrety. Deklaracje. Tekst polski - nowe thumaczenie, Poznań: Pallottinum 2002. 
-polityczny oprzeć swój dalszy rozwój. Na pewno czterdzieści lat ideologicznych eksperymentów i ich opłakane skutki w postaci: zacofania cywilizacyjnego, zrujnowanych i przestarzałych technologicznie gospodarek, zniszczonego środowiska naturalnego, ogromnego zadłużenia i niewydolności socjalnej państwa raczej zniechęcały do dalszego eksperymentowania. Powszechnie otworzono się na odbudowę systemu społeczno-ekonomicznego w oparciu o porządek realizowany w okresie powojennym w krajach wysokorozwiniętych polegający na demokratycznej formie władzy politycznej, wolnorynkowej gospodarce i własności prywatnej.

Niestety, pierwsze rezultaty rodziły powszechne przekonanie, że to otwarcie najczęściej przyjęło postać ślepego przenoszenia wzorców bez żadnej krytycznej refleksji czy selekcji. Nie brakowało głosów, że w pierwszej kolejności przeniesiono to, co najgorsze w społeczeństwach dobrobytu, a więc: konsumpcyjny styl życia, nierówności społeczne wewnątrz tego samego społeczeństwa, bezrobocie, afery, korupcję, materializm praktyczny, zatracenie właściwej hierarchii wartości, zeświecczenie życia, pornografię, narkotyki, terroryzm, itp.

Taka sytuacja powodowała na pewno zniechęcenie wśród szerokich warstw społeczeństwa, rodziła pytania o słuszność wybranej drogi, sens poświęceń. $\mathrm{Z}$ drugiej strony dostrzegało się potrzebę poważnej refleksji etycznej w oparciu o nauczanie społeczne Kościoła nad dokonującymi się zmianami społeczno-ekonomicznymi.

\section{Odnowione rozumienie kapitalizmu}

Upadek realnego socjalizmu w samym jego centrum po roku 1989 skłonił papieża do zadania nad wyraz aktualnych pytań:

Czy można powiedzieć klęska komunizmu oznacza zwycięstwo kapitalizmu jako systemu społecznego i że ku niemu winny zmierzać kraje, które podejmują dzieło przebudowy gospodarczej i społecznej? Czy jest to model, który należy proponować krajom Trzeciego Świata, szukającym właściwej drogi rozwoju gospodarczego i politycznego? (CA 42).

Odpowiedź papieża jest złożona i staje się równocześnie okazją do sformułowania odnowionego określenia kapitalizmu. Pomijając szersze analizy tej kwestii, warto przywołać jednak kilka fundamentalnych stwierdzeń, tym bardziej że ta sama metodologia dyskursu widoczna jest także przy prezentacji innych zagadnień dotyczących gospodarki wolnorynkowej. Jeżeli przez kapitalizm, pisał papież, zostanie określony system ekonomiczny, który „uznaje zasadniczą i pozytywną rolę przedsiębiorstwa, rynku, własności prywatnej i wynikającej 
z niej odpowiedzialności za środki produkcji, wolną ludzką inicjatywę" (CA 42), to odpowiedź na wyżej postawione pytanie będzie z pewnością pozytywna. Taki kapitalizm papież proponuje określać trafniejszymi wyrażeniami: „ekonomia przedsiębiorczości, ekonomia rynku, czy po prostu wolna ekonomia” (CA 42).

Jeśli jednak jako kapitalizm będzie rozumiany system, „w którym wolność gospodarcza nie jest ujęta w ramy systemu prawnego, wprzęgającego ją w służbę integralnej wolności ludzkiej i traktującego jako szczególny wymiar tejże wolności, która ma przede wszystkim charakter etyczny i religijny" (CA 42), to odpowiedź musi być przecząca.

Encyklika przypomina w tym kontekście także, że Kościół nie chce proponować żadnych modeli gospodarczych, lecz ma świadomość, iż realne i naprawdę skuteczne modele mogą się zrodzić tylko w ramach różnych historycznych sytuacji i dzięki wysiłkowi tych wszystkich, którzy w sposób odpowiedzialny podejmują konkretne problemy we wszystkich powiązanych ze sobą aspektach społecznych, gospodarczych, politycznych i kulturalnych (CA 43).

Istotny jest tu fakt, że system ekonomiczny, dla którego kapitalizm jest jedną z możliwych nazw, został umieszczony pomiędzy dwoma innymi systemami; jest on bowiem korygowany zarówno przez ramy systemu prawnego, jak i szerszą kulturę etyczną i religijną. Ład ekonomiczny trzeba widzieć w kontekście systemu politycznego oraz moralno-kulturalnego, które go modyfikują. Innymi słowy, logika rynku musi zostać dopełniona innymi wymiarami, w tym logiką państwa (polityczną) czy nawet, na co wskazał Benedykt XVI w encyklice Caritas in veritate, logiką daru ${ }^{8}$.

Pogłębiona analiza papieskich rozważań, dotyczących rozumienia kapitalizmu, nie jest przypadkowa. Miała ona na celu pokazanie z jednej strony metodologii encykliki, z drugiej zaś, będącego przedmiotem niniejszego studium, profetycznego charakteru enuncjacji. Analogiczny sposób dyskursu widoczny jest przy analizach innych istotnych elementów systemu gospodarczego, takich jak: rozumienie wolnego rynku, zysku, własności prywatnej, znaczenie państwa w dziedzinie gospodarczej itd.

\section{Odrzucenie systemu kolektywistycznego i błąd antropologiczny}

Profetyczna funkcja nauki społecznej Kościoła przejawia się również w jej zdolności do oceny i w razie konieczności także odrzucenia tego wszystkiego, co

\footnotetext{
${ }^{8}$ Benedykt XVI, Encyklika Caritas in veritate, (29 czerwca 2009), Watykan: Libreria Editrice Vaticana 2009, nr 37.Por. także: Ł. Niepsuj, La figura dell'imprenditore nell'economia mainstream (marshalliano-keynesiana) e nell'economia civile. Valutazione etico-antropologica alla luce della Dottrina Sociale della Chiesa, Roma 2020, s. 307-329.
} 
narusza podstawową zasadę życia społecznego, którą jest godność osobowa człowieka, i w konsekwencji wszelkich form alienacji. W tym kontekście Jan Paweł II w encyklice Centesimus annus w nawiązaniu do nauczania swoich poprzedników i do nauczania w Laborem exercens i w Sollicitudo rei socialis dokonuje gruntownej oceny systemu kolektywistycznego. Analizując wieloaspektowe deficyty tego modelu życia gospodarczo-społecznego, konstatuje, że:

podstawowy błąd socjalizmu ma charakter antropologiczny. Rozpatruje on bowiem pojedynczego człowieka jako zwykły element i cząstkę organizmu społecznego, tak że dobro jednostki zostaje całkowicie podporządkowane działaniu mechanizmu ekonomiczno-społecznego; z drugiej strony utrzymuje on, że dobro jednostki można urzeczywistnić, nie uwzględniając jej samodzielnego wyboru i niezależnie od przyjęcia przez nią w sposób indywidualny i wyłączny odpowiedzialności za dobro i zło. Człowiek zostaje w ten sposób utożsamiony z pewnym zespołem relacji społecznych, a jednocześnie zanika pojęcie osoby jako samodzielnego podmiotu decyzji moralnych, który podejmując je, tworzy porządek społeczny (CA 13).

Na podstawie tych błędnych założeń antropologicznych - fałszywej koncepcji człowieka - tworzy się system życia społecznego, w którym nie uznaje się naprawdę wolności człowieka ani jego podstawowych praw. Stąd też następuje zniekształcenie prawa, które nie tyle określa zakres wolności człowieka, co raczej prowadzi do jego ubezwłasnowolnienia i podporządkowania totalitarnemu aparatowi władzy. Jednym $\mathrm{z}$ narzędzi takiego podporządkowania $\mathrm{w}$ duchu kolektywizmu jest odrzucenie własności prywatnej, gdyż człowiek pozbawiony takiej własności i możliwości zarabiania na życie dzięki własnej przedsiębiorczości staje się zależny od całej machiny społecznej i zostaje poddany takiej kontroli. Utrudnia to, a niekiedy uniemożliwia podjęcie osobistej odpowiedzialności za własne życie, a tym samym staje na przeszkodzie tworzenia autentycznej wspólnoty ludzkiej. Przez zniszczenie struktur pośrednich nastąpiło w socjalizmie realnym, wraz ze zniszczeniem podmiotowości osoby, zniszczenie podmiotowości społeczeństwa (por. CA 13).

Jan Paweł II wskazał także na niektóre praktyczne konsekwencje dla kształtowania życia społecznego wynikające $\mathrm{z}$ tego podstawowego błędu socjalizmu. Wśród nich niezwykle destrukcyjną rolę dla życia społecznego odgrywa błędne ujmowanie skądinąd nieuchronnych konfliktów społecznych w duchu ideologii walki klas. Czym innym bowiem jest ujmowanie walki klas w pewnego rodzaju współzawodnictwo czy konkurencję, będące motorem sprawczym przemian społecznych i rozwoju, a czym innym idea takiego konfliktu społecznego, który nie jest ograniczony żadnymi względami natury etycznej czy prawnej. Tak rozumiana walka klas prowadzi z jednej strony do odrzucenia poszanowania godności osoby ludzkiej w drugim człowieku, a w konsekwencji także w sobie samym, 
a z drugiej - wyklucza wszelkie porozumienie, a więc także możliwość zbudowania prawdziwej wspólnoty. Podstawowym dobrem staje się nie dobro wspólne całej społeczności, ale korzyści jedynie określonej grupy społecznej. Jeśli doda się, że w praktyce ta walka klas realizuje się wszelkimi dostępnymi sposobami, dając pierwszeństwo zasadzie siły przed zasadą słuszności i prawa, i nie wykluczając kłamstwa, terroru i niszczenia ludności cywilnej, to widać, że socjalizm jest systemem pełnym pogardy dla osoby ludzkiej (por. CA 14).

Pomijając inne aspekty błędu antropologicznego, warto jeszcze podkreślić, że wiąże się on ściśle z materialistyczną koncepcją człowieka i życia społecznego, a więc ma swoje źródło w ateizmie. Człowiek rozpoznaje swoją transcendentną godność poprzez wypełnienie powołania danego od Boga. Jeśli odrzuca się Boga jako gwaranta tej godności, to w konsekwencji tworzy się taki porządek społeczny, w którym nie uznaje się prawdziwej godności i jednocześnie odpowiedzialności osoby. Ten ateizm wiąże się też z oświeceniowym racjonalizmem, który pojmuje rzeczywistość ludzką i społeczną w sposób mechanistyczny i jednocześnie neguje potrzebę zbawienia (por. CA 13).

\section{Centesimus annus a polska transformacja}

Przeprowadzona powyżej analiza odnowionego rozumienia kapitalizmu pokazała, że pozytywne wskazania encykliki co do kształtu możliwego ładu społeczno-gospodarczego nie dotyczą konkretnych rozwiązań modelowych, bo nie jest to zadaniem dokumentów papieskich, raczej należy je postrzegać jako projekt na płaszczyźnie wartości. Ma nim być społeczeństwo, w którym istnieją wolność pracy, przedsiębiorczość i uczestnictwo. Papież jest głęboko przekonany, że sprawnie funkcjonującego modelu społeczno-gospodarczego nie da się zbudować bez odpowiedniego zaplecza aksjologicznego i antropologicznego. Tak jak podstawowy błąd kolektywizmu miał charakter antropologiczny, tak zdrowa gospodarka i demokratyczne państwo musi bazować na: zdrowym etosie pracy, etosie przedsiębiorczości, wolności, uczestnictwie, pożądanych cnotach (odpowiedzialności, rzetelności, pracowitości, roztropności w podejmowaniu ryzyka, zdolności do inicjatywy).

$\mathrm{Z}$ perspektywy trzech dekad, nie tylko od czasu opublikowania encykliki, ale także rozpoczętych na przełomie ostatniej dekady ubiegłego wieku wieloaspektowych zmian ustrojowych w naszej części Europy, warto w kontekście profetycznego wymiaru encykliki Centesimus annus postawić pytanie: co konkretnego wniosła ona w proces transformacji w Polsce?

Odpowiedzi na wyżej postawioną kwestię można próbować udzielić na kilku płaszczyznach. W wymiarze ogólnym encyklika na pewno uczyła patrzenia całościowego, widzenia wielorakich związków między różnymi faktorami two- 
rzącymi życie społeczne, a więc między polityką, gospodarką i kulturą, podkreślając przy tym moralne wymiary ludzkiej działalności. Oprócz tego pokazywała niebezpieczeństwo przyznania priorytetu wąsko rozumianej gospodarce, czyli ostrzegła przed błędem ekonomizmu.

Zawierała dużą porcję wiedzy o współczesnym świecie, dawała orientację w gąszczu zagadnień, ukazywała kierunek działania i przedstawiała pewien docelowy typ kultury i cywilizacji, której fundamentem, co jest charakterystyczne dla całości nauczania społecznego Kościoła, było uznanie godności i praw człowieka. Za główny powód upadku komunizmu encyklika nie uznała klęski gospodarczej czy nieudolności biurokracji, ale bunt człowieka. W świecie niewoli narodziła się wolność, bowiem to wolni ludzie obalili komunizm. Znamienne w tym kontekście są słowa encykliki: „lekceważenie natury człowieka, stworzonego dla wolności, jest nie tylko niedozwolone z punktu widzenia etycznego, ale i praktycznie niemożliwe" (CA 25). Widać tu kolejne nawiązanie do błędu antropologicznego. W konsekwencji jedyną koncepcją rozwoju może być tylko rozwój integralny, w którym istotne znaczenia odgrywa nie tylko dobrobyt, ale także: dostęp do kultury, pierwszeństwo pracy, podmiotowość społeczeństwa, czyli szeroki, swobodny udział w życiu społecznym.

W wymiarze makrospołecznym, a precyzyjnie makroekonomicznym, encyklika daleka jest od wskazania modelu do naśladowania, co mogło być dla niektórych rozczarowaniem. $Z$ drugiej strony krok ten zdaje się precyzyjnie thumaczyć: nie ma jednego uniwersalnego modelu, jest on niemożliwy, mógłby być co najwyżej tylko ideologiczną utopią. Konkretne modele w poszczególnych krajach muszą być różne, winny jednak odwoływać się do uniwersalnej podstawy aksjologicznej (por. CA 43).

Centesimus annus uczy zdrowego realizmu w podejściu do gospodarki, pozwalała przezwyciężyć zakorzenione stereotypy w postaci pozostającej w pamięci marksistowskiej krytyki wolnego rynku, krytyki zysku i własności prywatnej. Z drugiej zaś, dokonując wyważonej legitymizacji moralnej podstawowych zasad gospodarki liberalnej i wskazując przy tym na niektóre deficyty samego rynku i jego mechanizmów, demaskowała funkcjonujące w świadomości społecznej nierealistyczne mity na temat funkcjonowania gospodarki rynkowej, dotyczące chociażby kapitalistycznego bogactwa jednak bez kapitalistycznej pracy. Legitymizacji tej nie sprzeciwia się to, co Jan Paweł II nazywa alienacją pracy. Pojęcie alienacji, używane i nadużywane przez marksizm, uzyskuje nowe znaczenie: polega na odwróceniu relacji środków i celów. To nie człowiek jest dla ekonomii, lecz ekonomia dla człowieka (por. CA 41).

Oczywiście szczególne znaczenie encyklika miała dla krajów postkomunistycznych, była bowiem skierowana do ludzi, którzy nosili w sobie żywe wspomnienie komunizmu. Uczyła rozumieć, czym jest odpowiedzialność i wska- 
zywała na jej potrzebę. Dla Polaków przesłanie encykliki miało tym większą wartość, że znalazły się w niej słowa o Polsce, o solidarności, o pokojowej walce, która „wymagała wielkiej przytomności umysłu, umiarkowania, cierpień i ofiar" (CA 25). Przypomnieniem tym Jan Paweł II nadawał polskim wydarzeniom szczególne znaczenie.

W zakresie życia politycznego sprawą podstawową była odbudowa państwa. Także w tym aspekcie wskazania Jana Pawła II miały istotne znaczenie, choć nie rozstrzygały wszystkich wątpliwości, bo nie mogły. Autor bronił koncepcji „państwa praworządnego” (CA 44), „doceniał demokrację” (CA 46), potwierdzał „zasadę pomocniczości” (CA 48) jako podstawę działalności państwa, jednocześnie przypominał państwu moralny obowiązek interwencji w życie gospodarcze, zwłaszcza w sprawie ubogich, oraz w życie kulturalne. Nie podzielał poglądu, jakoby filozofią demokratycznego państwa miał być ,agnostycyzm i sceptyczny relatywizm” (CA 46), powinna nią być raczej ,poprawna koncepcja osoby ludzkiej" (CA 11).

Państwo powinno przestrzegać praw człowieka. Tak więc państwu totalitarnemu, które się rozsypało, przeciwstawiał Jan Paweł II państwo „ładu prawnego” o zdecydowanie etycznym zabarwieniu. W państwie takim jest miejsce dla Kościoła, ponieważ jego metodą działania jest „,poszanowanie wolności” (por. CA 46).

Można w tym miejscu postawić kolejne pytanie: czy wraz z publikacją encykliki dylematy, przed którymi stanęły państwa podejmujące transformację, zostały rozstrzygnięte? Na pewno nie, co widać choćby w tym, że wiele problemów, przed którymi stali budowniczowie państwa w okresie postkomunistycznym, ciągle jest przedmiotem sporów politycznych. Można tu wspomnieć także dyskusje na temat: nauczania religii w szkołach, prawnej ochrony życia, neutralności światopoglądowej urzędników państwowych, klauzul sumienia czy chociażby kwestii, jak zharmonizować ustawodawstwo państwowe, które musi być jedno i obowiązywać wszystkich, z zasadami i normami etyki, których w każdym społeczeństwie pluralistycznym jest wiele i które często przeciwstawiają się sobie?

\section{Recepcja encykliki}

Przyjęta hipoteza badań zakłada istnienie profetycznego, a więc także poniekąd opiniotwórczego wymiaru trzeciej encykliki społecznej Jana Pawła II jako przesłania na czas transformacji. Warto w ostatniej jego części podjąć kwestię recepcji encykliki w kręgach ekonomicznych i właśnie opiniotwórczych, tym bardziej że oczekiwana w związku z nadchodzącym stuleciem ukazania się Rerum novarum encyklika, poprzedzona różnymi rzekomymi „przeciekami” na temat swej zawartości, od samego początku wzbudziła szerokie zainteresowanie w środowiskach gospodarczych i opiniotwórczych Zachodu. Stała się przedmiotem debat 
i analiz nie tylko wśród katolików, poświęcono jej wiele uwagi w licznych periodykach religijnych i politycznych.

Ukazanie recepcji encykliki siłą rzeczy musi przyjąć postać jedynie ogólnej panoramy stanowisk bez analizowania poszczególnych przyczynków czy wypowiedzi. W tym kontekście warto postawić pytanie: co najbardziej uderza w tych reakcjach? Warto zwrócić przede wszystkim uwagę na ogromną różnorodność interpretacji: jedni chcieli widzieć w nowej encyklice wyraz aprobaty ze strony Magisterium Kościoła dla instytucji demokratycznego kapitalizmu czy społecznej gospodarki rynkowej, inni - przeciwnie - odczytali ją jako kolejny wyraz moralnego potępienia współczesnej cywilizacji. W ocenach tych nietrudno było dostrzec wiele jednostronności czy wręcz uprzedzeń, ale zarazem były one przykładem niezwykle poważnego stosunku do nauki papieża, czego w Polsce, w pierwszym okresie recepcji encykliki, paradoksalnie zabrakło.

Już sama zapowiedź encykliki budziła pewien niepokój w niektórych wypowiedziach pochodzących zarówno z kręgów etyków społecznych, jak i kościelnie zaangażowanych środowisk gospodarczych. Obawiano się dokumentu papieskiego, który byłby zbiorem życzeń i apeli, a w swojej ocenie rozwoju społeczno-gospodarczego mijałby się z rzeczywistością. Powodem była ocena poprzedniej w niektórych kwestiach mocno krytykowanej encykliki społecznej, która dostarczyła kolejnych argumentów zwolennikom „Äqudisistanzthese”, czyli jednakowego dystansu katolickiej nauki społecznej względem kapitalizmu i komunizmu. Tym razem podnoszone obawy nie znalazły potwierdzenia. Najnowsza encyklika dołożyła starań po tym, jak jeden $\mathrm{z}$ biegunów dotychczasowej polaryzacji zniknął lub przynajmniej istotnie został osłabiony o zróżnicowaną ocenę kapitalizmu (por. CA 42).

Encyklika została zasadniczo oceniona pozytywnie, przy czym ocena ta była uzależniona od przyjętych uprzednio założeń. W szerokich kręgach, także spoza chrześcijan, powitano z uznaniem fakt, że w stulecie Rerum novarum Kościół zabrał głos, kierując się nie tylko chęcią przypomnienia tego wydarzenia, lecz również odpowiedzialnością za społeczeństwo godne człowieka u progu trzeciego tysiąclecia. Po upadku realnego socjalizmu istniało niebezpieczeństwo, że pytanie o przyszłość porządku społeczno-politycznego zostanie zdominowane przez decydentów gospodarki i polityki, spychając do lamusa odniesienia do wartości moralno-religijnych. Centesimus annus, umieszczając odbudowę porządku gospodarczego i politycznego w kontekście wartości i zasad moralnych, stała się zauważonym podmiotem w tej dyskusji.

Encyklika była postrzegana również jako znaczny postęp w dialogu Kościoła z nowoczesnym światem. Wiele uprzedzeń, wynikających z przeszłości i obciążających styl wyrażania i myślenia Urzędu Nauczycielskiego, zostało usuniętych. Encyklika Centesimus annus jawiła się też jako próba znalezienia relacji między dzisiejszymi problemami społecznymi a życiem wiary. Dla tych chrześcijan, którzy czują się bezsilni w obliczu nowoczesnego życia gospodar- 
czego, może ona stanowić pierwszą orientację, jak połączyć te doświadczenia $\mathrm{z}$ własną wiarą.

Jeszcze żaden dokument papieski nie był tak życzliwie nastawiony do konkurencji i tak prorynkowy. Dotychczasowy zarzut o brak otwarcia Kościoła na nowoczesny porządek gospodarczy czy w ogóle na liberalne ujęcie społeczeństwa (również ,państwa prawa”) tracił rację bytu. Encyklika ostatecznie otworzyła szeroko drzwi do poważnej dyskusji między katolicką nauką społeczną a naukami ekonomicznymi, co nie przeszkodziło papieżowi wyrazić także krytyki względem zachodniego systemu gospodarczego, zwłaszcza w kontekście kulturowych i duchowych braków.

Analizując z perspektywy trzech dekad ówczesną recepcję encykliki, należy również wspomnieć o wypowiedziach krytycznych. Dotyczyły one pojedynczych stwierdzeń encykliki lub pominięcia któregoś z aktualnych problemów. Często spotykanym punktem krytyki był sposób potraktowania problemu demograficznego czy ujęcie polityki rozwojowej. Niektóre kręgi wysuwały także zarzut wobec Centesimus annus, że gdy mówi o socjalizmie, ujmuje go w jego dawnym ujęciu, a pod pojęciem realnego socjalizmu rozumie kolektywistyczny komunizm. Z ubolewaniem przyjęto tam fakt, że także w stulecie wydania Rerum novarum Kościół nie zrewidował swego negatywnego osądu o każdym rodzaju socjalizmu wyrażonego przez Piusa XI w encyklice Quadragesimo anno.

W pierwszych komentarzach na temat encykliki dało się zauważyć pewną symptomatyczną prawidłowość. Mianowicie pierwsze informacje, oparte na słabej znajomości treści, charakteryzowały się ogromną rozbieżnością ocen, które były popierane pojedynczymi fragmentami tekstu. Niemniej jednak można było także skonstatować, że od Kościoła oczekuje się moralnej oceny zachodzących zjawisk. Akceptacja ze strony Kościoła byłaby sygnałem o słuszności wyborów widzianych szerzej niż tylko przez rachunek strat i zysków.

$\mathrm{Na}$ koniec warto jeszcze w paru zdaniach opisać odbiór encykliki w polskich mediach i środowiskach opiniotwórczych. Paradoksem recepcji encykliki w Polsce jest fakt, że najlepszy do niej komentarz opublikowała, używając dzisiejszych klasyfikacji ideologicznych, lewicowo-liberalna „Polityka” (autorstwa Władysława Piwowarskiego). W periodykach katolickich na uwagę zasługiwała interesująca dyskusja redakcyjna przedstawiona na łamach „Więzi” oraz przyczynki Macieja Zięby oraz Anieli Dylus. Niestety, trudno było wskazać jakąś istotną debatę $\mathrm{z}$ udziałem głównych decydentów gospodarki polskiej, co było o tyle dziwne, że wówczas prawie wszystkie ugrupowania w polskim parlamencie, od postkomunistów począwszy, a na liberałach skończywszy, odwoływały się w jakimś stopniu do katolickiej nauki społecznej. Innym problemem była oczywiście kwestia, co rozumieli przez katolicką naukę społeczną.

Profetyzm encykliki Centesimus annus pozostaje sprawą otwartą, bowiem, podobnie jak miało to miejsce w przypadku encykliki Rerum novarum, papie- 
skie wizje i nakreślone kierunki są nieustannie w stanie realizacji, ciągle przy tym zachowując swą aktualność i ciągle domagając się zgłębiania i analizowania. Wszystkim tym badaniom niech przyświeca optymistyczna, co ważne dla znaków prorockich, uwaga Richarda D. Landa, zaliczonego w swoim czasie przez „Time Magazine” do grona 25 najbardziej wpływowych ewangelików i prezydenta Ethics \& Religious Liberty Commission. W jednym z esejów poświęconych encyklice napisał, że Jan Paweł II nie mówi w niej równocześnie o rzeczach złych i dobrych, z czym tak często można się spotkać w dzisiejszym świecie. Centesimus annus oferuje jedynie wiadomości dobre, lepsze i najlepsze. Wiadomością dobrą jest wyraźne i bezprecedensowe uznanie przez papieża wydajności i efektywności wolnorynkowego systemu gospodarczego jako najbardziej skutecznego narzędzia wykorzystywania zasobów i zaspokajania potrzeb. Wiadomością lepszą jest fakt, iż papieska sankcja udzielona wolnorynkowemu systemowi kapitalistycznemu jest warunkowa i ograniczona licznymi uwagami na temat jego słabości i braków. Wiadomością najlepszą zawartą w encyklice jest stwierdzenie, że ekonomia posiada pewne immanentne ograniczenia i że w najlepszym wypadku może jedynie utrzymywać i umacniać system polityczny i kulturowy oparty na moralnej i duchowej prawdzie 9

\section{Zakończenie}

Będąca przedmiotem dla podjętej naukowej refleksji trzecia encyklika społeczna Jana Pawła II Centesimus annus w duchu właściwie pojętej profetycznej funkcji nauczania społecznego Kościoła wyraża niewątpliwie aprobatę dla tego, co nazywa „ekonomią przedsiębiorczości, ekonomią rynku czy wolną ekonomią” (por. CA 42) zakorzenioną w systemie prawnym oraz moralno-kulturowym, które ją modyfikują. Odrzuca jednocześnie ona stwierdzenie, że ten wolny system gospodarczy może zaspokoić wszystkie ludzkie potrzeby. Zauważa jego deficyty i niewystarczalność, odróżniając jednak sam system od jego kontekstu etycznego i kulturalnego (rozumianego jako ideologia liberalizmu). Dostrzegając rozliczne deficyty kapitalizmu, możliwe także do skonstatowania w dotychczasowych przemianach ustrojowych w Europie Środkowo-Wschodniej, aprobuje jednocześnie sam model nowoczesnej gospodarki rynkowej jako zasadniczo zgodny z nauką społeczną Kościoła.

Warto na koniec raz jeszcze przypomnieć, że choć zasadnicze przyczyny upadku reżymów Europy Środkowo-Wschodniej były niewątpliwie natury ekono-

${ }^{9}$ R. D. Land, Good News, Better News, Best News, w: A New Worldly Order: John Paul II and Human Freedom, ed. G. Weigel, University Press Of America 1992, s. 101-106. 
micznej, społecznej i politycznej, to jednak była także głębsza przyczyna natury etycznej, antropologicznej i duchowej. Podstawowy błąd marksizmu miał „charakter antropologiczny" (CA 13). Fałszywa i nieadekwatna antropologia dała początek ekonomicznej i politycznej rzeczywistości, której niesprawiedliwość i nieludzkość z konieczności skazywały ją na upadek. Zmusza to do jeszcze większej czujności $\mathrm{w}$ analizach poszczególnych modeli gospodarczych na wartość centralną absolutną w porządku naturalnym - jaką jest niewątpliwie godność osoby ludzkiej. Pytania o respektowanie tej godności i wypływające z niej prawa osoby będą zawsze ostatecznym probierzem dla demokratycznego charakteru wszelkich form ustrojowych życia politycznego czy gospodarczo-społecznego, o czym za każdym razem przypomina lektura encykliki Centesimus annus.

\section{Streszczenie}

Przedmiotem artykułu jest profetyczny wymiar trzeciej encykliki społecznej Jana Pawła II jako przesłania na czas transformacji dla krajów Europy Środkowo-Wschodniej po upadku komunizmu. Centesimus annus była głosem Kościoła, który, zgodnie z naturą własnej nauki społecznej i jej profetyczno-krytyczną specyfiką, ma prawo do wydawania osądu w sprawach społecznych. Publikacja pokazuje różne aspekty profetyzmu encykliki, podkreślając jej ponadczasowość i aktualność.

\section{Slowa kluczowe}

Centesimus annus, Jan Paweł II, nauka społeczna Kościoła, błąd antropologiczny

\section{The Prophetic Dimension of Centesimus annus. Analysis from the Perspective of the 30th Anniversary of the Publication of the third Social Encyclical of John Paul II}

\section{Summary}

The subject of the article is the prophetic dimension of the third social encyclical of John Paul II as a message for the transformation of the countries of Central and Eastern Europe after the fall of communism. Centesimus annus was the voice of the Church, which, in accordance with the nature of its own social teaching and its prophetic-critical specificity, has the right to make judgment in social matters. The publication shows various aspects of the prophetism of the encyclical, emphasizing its timelessness and topicality.

\section{Keywords}

Centesimus annus, John Paul II, the social teaching of the Church, anthropological error 


\section{Bibliografia}

Benedykt XVI, Encyklika Caritas in veritate, (29 czerwca 2009), Watykan: Libreria Editrice Vaticana 2009.

Cuda J., Praktyczno-społeczne kryterium wiarygodności objawionego sensu historii. Analityczno-syntetyczne studium inspirowane paradygmatem nowej teologii politycznej, Katowice 1999.

Jan Paweł II, Encyklika Centesimus annus, (1 maja 1991), Watykan: Libreria Editrice Vaticana 1991.

Jan Paweł II, Encyklika Sollicitudo rei socialis, (30 grudnia 1987), Watykan: Libreria Editrice Vaticana 1988.

Land R. D., Good News, Better News, Best News, w: A New Worldly Order: John Paul II and Human Freedom, ed. G. Weigel, University Press Of America 1992, s. 101-106.

List spoteczny Episkopatu USA: Sprawiedliwość gospodarcza dla wszystkich. Katolicka nauka społeczna a gospodarka USA, (18 listopada 1986), w: Kościót wobec wspótczesnych problemów życia gospodarczego. Spoteczne dokumenty episkopatów, red. S. Fel, J. Kupny, Lublin 2002, s. 19-137.

Niepsuj Ł., La figura dell'imprenditore nell'economia mainstream (marshalliano-keynesiana) e nell'economia civile. Valutazione etico-antropologica alla luce della Dottrina Sociale della Chiesa, Roma 2020, s. 307-329.

Papieska Rada „Iustitia et Pax”, Kompendium Nauki Społecznej Kościoła, Kielce 2005.

Sobór Watykański II, Konstytucja duszpasterska o Kościele w świecie współczesnym Gaudium et spes, (7 grudnia 1965), w: Sobór Watykański II, Konstytucje. Dekrety. Deklaracje. Tekst polski - nowe thumaczenie, Poznań: Pallottinum 2002, s. 526-606.

Zuberbier A., Teologiczny wymiar encykliki ,, Rerum novarum”, „Studia Theologica Varsaviensia" 30(1992), nr 1, s. 69-76. 